Grassroots Journal of Natural Resources, Vol. 2 No. 1-2 (2019)

http://journals.grassrootsinstitute.net/journal1-natural-resources/

ISSN: 2581-6853

\title{
Understanding the Distribution, Conservation and Threats to Pangolin (Manis spp.)
}

\author{
Uchita Lamichhane $^{* 1}$, Basudev Pokhrel ${ }^{1}$ \\ ${ }^{1}$ Faculty of Forestry, Agriculture and Forestry University, Hetauda, Nepal \\ *Corresponding author (Email: uniqueuchita123@gmail.com)
}

How to cite this paper: Lamichhane, $U$. and Pokhrel, B. (2019). Understanding the Distribution and Conservation of and Threats to Pangolin (Manis spp.). Grassroots Journal of Natural Resources, 2(1-2): 37-44. Doi:

https://doi.org/10.33002/nr2581.6853.02124

Received: 29 April 2019

Reviewed: 07 May 2019

Provisionally Accepted: 13 May 2019

Revised: 17 May 2019

Finally Accepted: 20 May 2019

Published: 20 June 2019

Copyright $\odot 2019$ by author(s) and

The Grassroots Institute.

This work is licensed under the Creative Commons Attribution International License (CC BY 4.0). http://creativecommons.org/licenses/by/4.0/
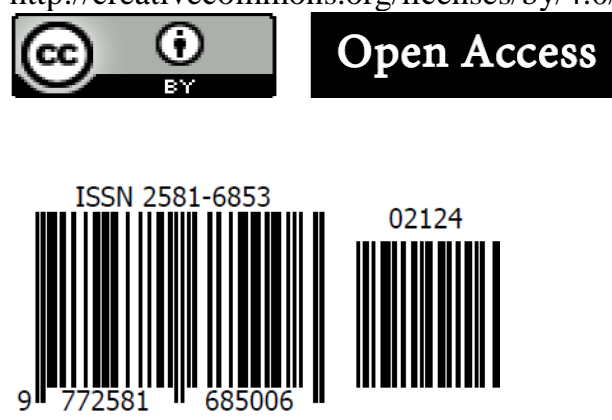

\begin{abstract}
This article is based on the study carried out in Rani Community Forest (CF) of Makwanpur district of Nepal to assess the distribution of and key threats to pangolin along with its conservation efforts at the community level. The methodology includes searching the direct and indirect signs of pangolin (burrows, footprints, faecal material). Simple random sampling method was applied for the collection of social information related to pangolin. 130 burrows (44 new and 86 old) were recorded during the survey. Distribution of burrows was clumped type and not uniform throughout all elevations. Most of the burrows were found in the elevation range of 500$600 \mathrm{~m}$. Most of the people had awareness about pangolin while only few respondents had seen it directly inside the community forest. It indicates that there was occurrence of pangolin in the community forest. Key threats to Pangolin were construction activities, drying water resource, rapid urbanization, habitat loss, lack of food, overgrazing, mining, deforestation, poaching, predation of associated animal species, and forest fire. Among them the construction activities were considered as biggest threat to pangolin. Various community-based conservation programs were initiated by authorities of Rani Community Forest; however, these programs were still not effective for the conservation of pangolin.
\end{abstract}

Keywords

Pangolin; Distribution; Threat; Conservation 
Doi: https://doi.org/10.33002/nr2581.6853.02124

\section{Introduction}

The word "Pangolin" is derived from Malayan word "Pengguling", meaning something that rolls up. Pangolin, often called scaly ant eaters, is a nocturnal mammal covered with tough, overlapping scales. It is shy, non-aggressive, solitary and burrowing strange mammal (Dickman, 2001). Among four species of pangolins found in Asia, two are found in Nepal: Chinese Pangolin (Manis pentadactyla) and Indian Pangolin (Manis crassicaudata) (Baral and Shah, 2008; Jnawali et al., 2011). In Nepal, earlier it was found in 12 districts; but, according to a study, 43 districts are now home to pangolins (RSS, 2016). In Nepal, Chinese Pangolin is distributed from Eastern to Central region and Indian Pangolin in Shuklaphanta National Park, Parsa National Park, Chitwan National Park and Bardiya National Park (Shrestha, 2003; Suwal, 2011). In Makwanpur district, Pangolins are distributed from southern to northern part, and are also found in Rani Community Forest (6-7 in number, including both Chinese and Indian Pangolins) (Raut, 2015). Globally, pangolins are greatly poached for their meat and scales. Recently, Central Investigation Bureau of Nepal Police arrested two Chinese nationals, who were allegedly involved in smuggling $162 \mathrm{~kg}$ of pangolin scales from Africa (The Himalayan Times, 2018). Global conservation status of Chinese Pangolin is critically endangered, whereas Indian Pangolin is endangered (IUCN, 2017). Though many researches on pangolin has been done in recent years, information on distribution is still insufficient in Nepal (Chalise, 2008). In the same way, information on distribution in current study area is also insufficient. Lots of conservation efforts have been carried out, but most of them are somehow hindered by lack of knowledge about their distribution and threats (Challender, 2009). Therefore, this study would be helpful to locate the current distribution of pangolin within study area and at the same time present threats of pangolin would assist in controlling the threats. It would also be helpful to identify whether local communities were involved in conservation activities or not.

\section{Methods and Materials}

\section{Study Area}

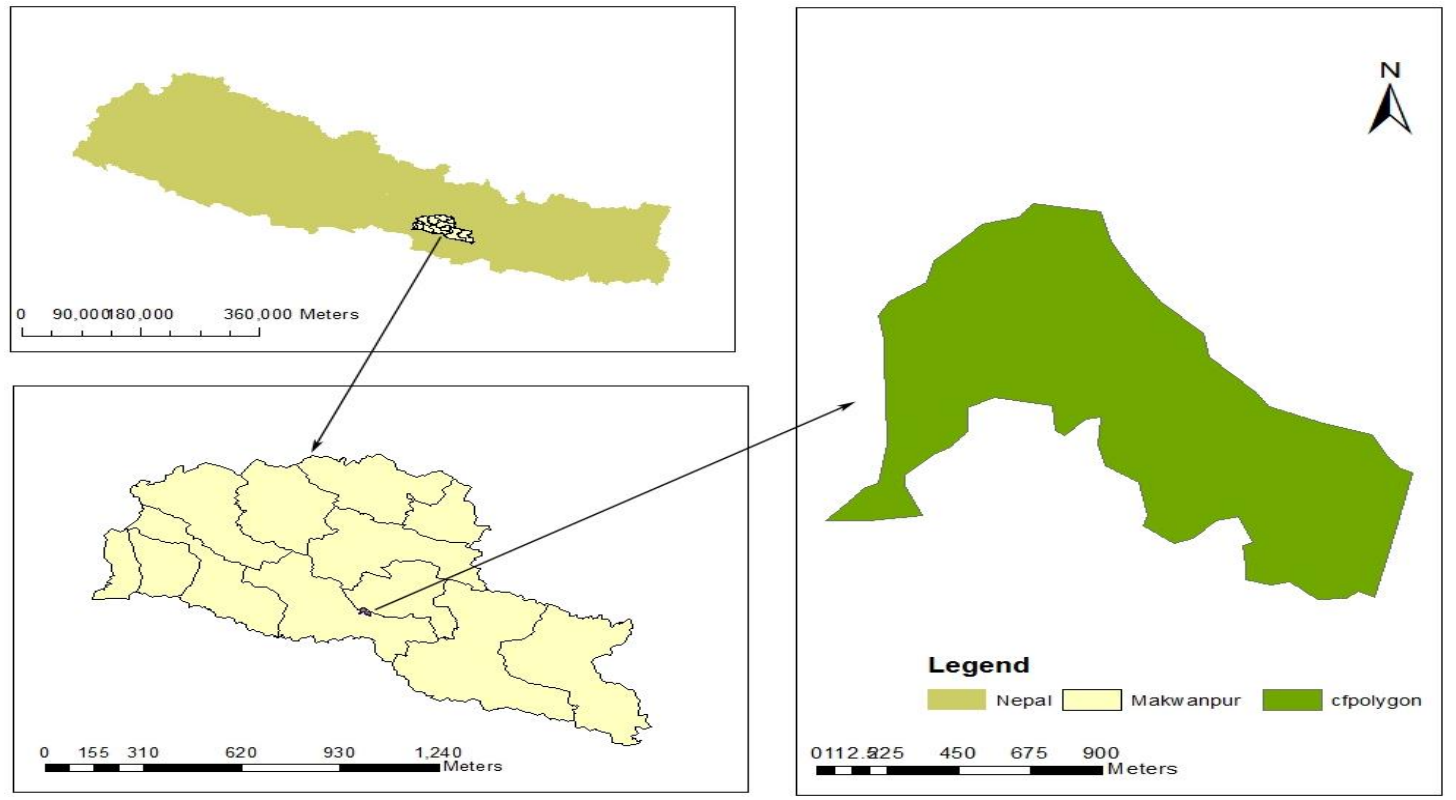

Figure 1: Map showing Rani Community Forest 
The study was conducted in Rani Community Forest of Hetauda-6, Makwanpur, Province No.3. The representative GPS points of study area were X: 0309677, Y: 3033889. The total area of study site was 151.87 ha with total household of 787. The study area lied in southern aspect with the elevation range of 350-750m. Dominant plant species were Sal (Shorea robusta), Saj (Terminalia alata), Chilaune (Schima wallichii), Champ (Michelia champaca), Masala (Eucalyptus sp.), Sisoo (Dalbergia sisoo), etc.

\section{Data Collection}

Under primary data collection, first of all the preliminary survey was carried out in the concerned area to understand the situation of pangolin in that area. The whole area of community forest was searched to spot direct and indirect signs of pangolin (burrows, foot tracks, faecal material). The sites having occurrence of pangolin was marked as positive and their geographical coordinates were recorded using global positioning system (GPS). Later the distribution map was developed using ArcGIS 10.3.1. The numbers of old burrows and new burrows were also counted. They were distinguished by the characteristics given in table 1 .

Table 1: Difference between old and new burrow

\begin{tabular}{|l|l|}
\hline Old Burrow & \multicolumn{1}{|c|}{ New Burrow } \\
\hline Soil deposited around burrow was not fresh. & $\begin{array}{l}\text { Soil deposited around new burrow seemed to } \\
\text { be fresh. }\end{array}$ \\
\hline They were covered by leaf litter and cobweb. & They were not covered by leaf litter and cobweb. \\
\hline
\end{tabular}

Simple random sampling method was applied for the collection of social information related to pangolin. Using $10 \%$ sampling intensity, questionnaire survey was carried out by directly administering semi-structurally scheduled questionnaire, which was prepared before field visit.79 respondents were interviewed (users of Rani Community Forest). Semi-structured interviews were also conducted with experts, concerned authorities, user's group committee members, and local leaders to determine key threats to and various conservation programs related to pangolin. Secondary data was collected from various published and unpublished documents, articles, books, brochures, websites and other sources.

\section{Data Analysis}

The data collected during field visit and survey was thoroughly analyzed using appropriate statistical tools depending upon the nature of data. Data was analyzed both qualitatively and quantitatively. Distribution pattern in the study area was determined by calculating the ratio of variance and mean $\left(S^{2} / a\right)$.

Variance $=S^{2}=1 /\left(n \sum(x-a)^{2}\right)$

Where, $\mathrm{x}=$ sample value, $\mathrm{a}=$ mean value

If $S^{2} / a=1$, Distribution is random

If $S^{2} / a<1$, Distribution is regular

If $\mathrm{S}^{2} / \mathrm{a}>1$, Distribution is clumped

Analytical technique for preference ranking of threats to Pangolin: 
Average Ranking Score $=\underline{x 1 . w 1+x 2 . w 2+\ldots . . x n . w n}$

$$
\text { Total no. of respondents }
$$

Where, $\mathrm{w}=$ weight of ranked position

$$
\begin{aligned}
& \mathrm{n}=\text { no. of choice } \\
& \mathrm{x}=\text { response count for answer choice }
\end{aligned}
$$

Weights are applied in reverse. In other words, the respondents most preferred choice (which they rank \#1) has the largest weight and their least preferred choice (which they rank in last position) has weight 1 .

\section{Result and Discussion}

\section{Distribution}

Out of 130 burrows recorded, 86 burrows were found to be old burrows, whereas 44 burrows were found to be new burrows. Distribution map of pangolin with new and old burrow in the study area is shown in Figure 2.

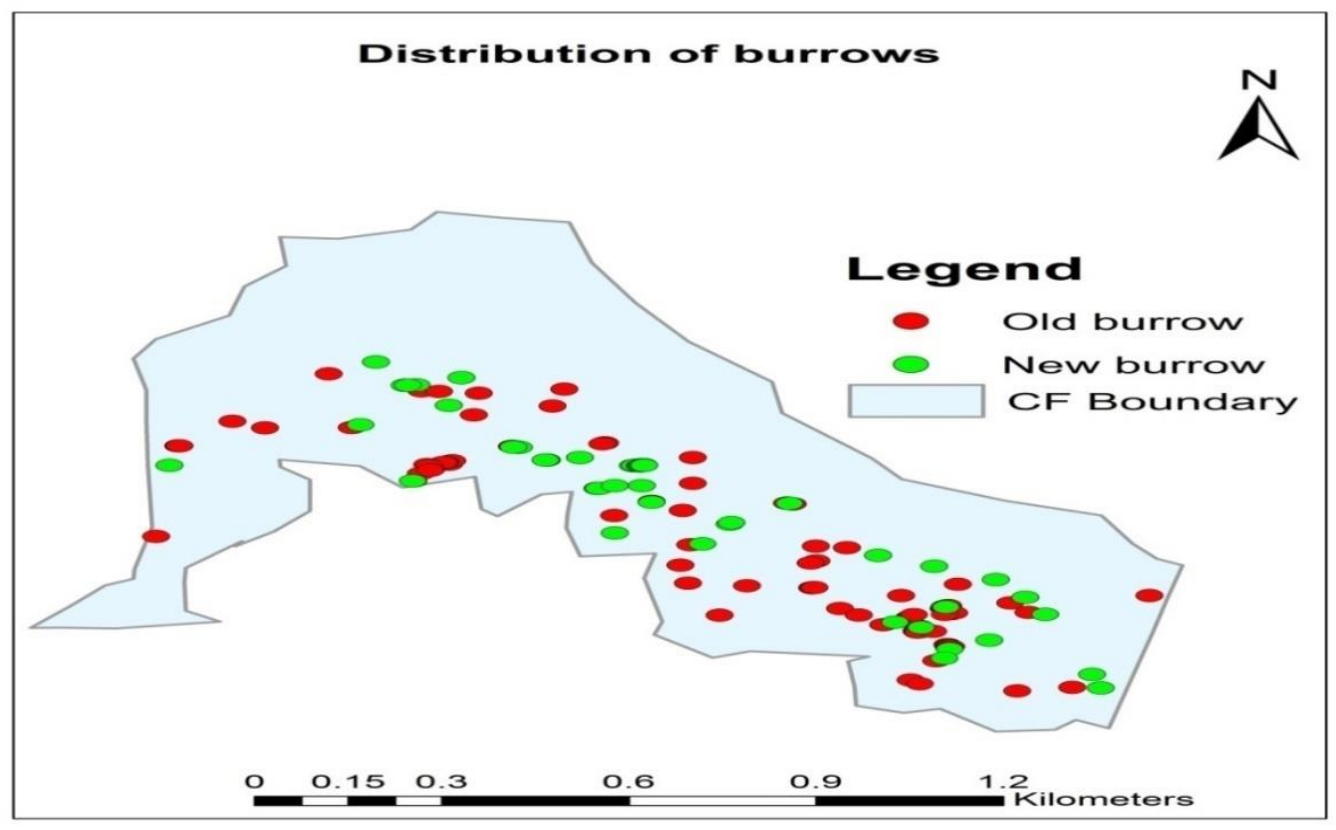

Figure 2: Distribution of burrows

Data in Table 2 shows the distribution pattern of pangolin through indirect sign (burrows). In the tabulated data, variance/mean $=20.022$, which is greater than 1 . So, distribution pattern was 'clumped' type in Rani Community Forest. 
Doi: https://doi.org/10.33002/nr2581.6853.02124

Table 2: Table showing variance

\begin{tabular}{|l|l|l|l|l|}
\hline Elevation (meter) & \multicolumn{1}{|c|}{$\begin{array}{c}\text { Observed value }(O) \\
(\text { No. of burrow) }\end{array}$} & $\begin{array}{c}\text { Expected } \\
\text { Value }(E)\end{array}$ & \multicolumn{1}{|c|}{$(O-E)$} & $(O-E)^{2}$ \\
\hline $400-500$ & 46 & 43.33 & 2.67 & 7.13 \\
\hline $500-600$ & 78 & 43.33 & 34.67 & 1202.01 \\
\hline $600-700$ & 6 & 43.33 & -37.33 & 1393.53 \\
\hline Total & 130 & & & 2602.67 \\
\hline Mean & 43.33 & & Variance & 867.56 \\
\hline
\end{tabular}

Table 3: Number of burrows in different elevations

\begin{tabular}{|c|c|}
\hline Elevation(meter) & Number of burrows \\
\hline $400-500$ & 46 \\
\hline $500-600$ & 78 \\
\hline $600-700$ & 6 \\
\hline
\end{tabular}

The table 3 shows elevation wise distribution of burrows. The maximum numbers of burrows were found between 500-600 meter above mean sea level, whereas minimum number of burrows were found between $600 \mathrm{~m}$ and $700 \mathrm{~m}$ in this community forest. Heath (1992) and Wu et al. (2004) indicated pangolin's preference of habitat up to $1550 \mathrm{~m}$, while Chao (2001) and Chakraborty, Ramakrishna and Chakraborty (2002) recorded up to $2000 \mathrm{~m}$. Out of 79 respondents, 26 respondents $(33 \%)$ had seen pangolin directly, 41 respondents $(52 \%)$ had heard about pangolin and 12 respondents (15\%) didn't know about pangolin. 53 respondents $(67 \%)$ had seen burrow of pangolin in this community forest, whereas 26 respondents $(33 \%)$ had not seen any sign of presence of pangolin. This indicates that there was occurrence of pangolin inside this community forest.

\section{Threat Analysis}

Key threats were identified through key informants survey and these key threats were taken as references (indices) for preference ranking as a questionnaire survey to the users of Rani Community Forest. The key threats which were identified inside this community forest are:

- Deforestation

- Poaching

- Mining

- Forest fire

- Scarcity of water resources

- Development construction activities

- Rapid urbanization resulting into habitat loss

- Predation of associated wild animal species

- Lack of food

- Overgrazing

These major key threats were ranked or prioritized by 67 users (who had knowledge about pangolin), which showed the results as represented in Figure 3. 


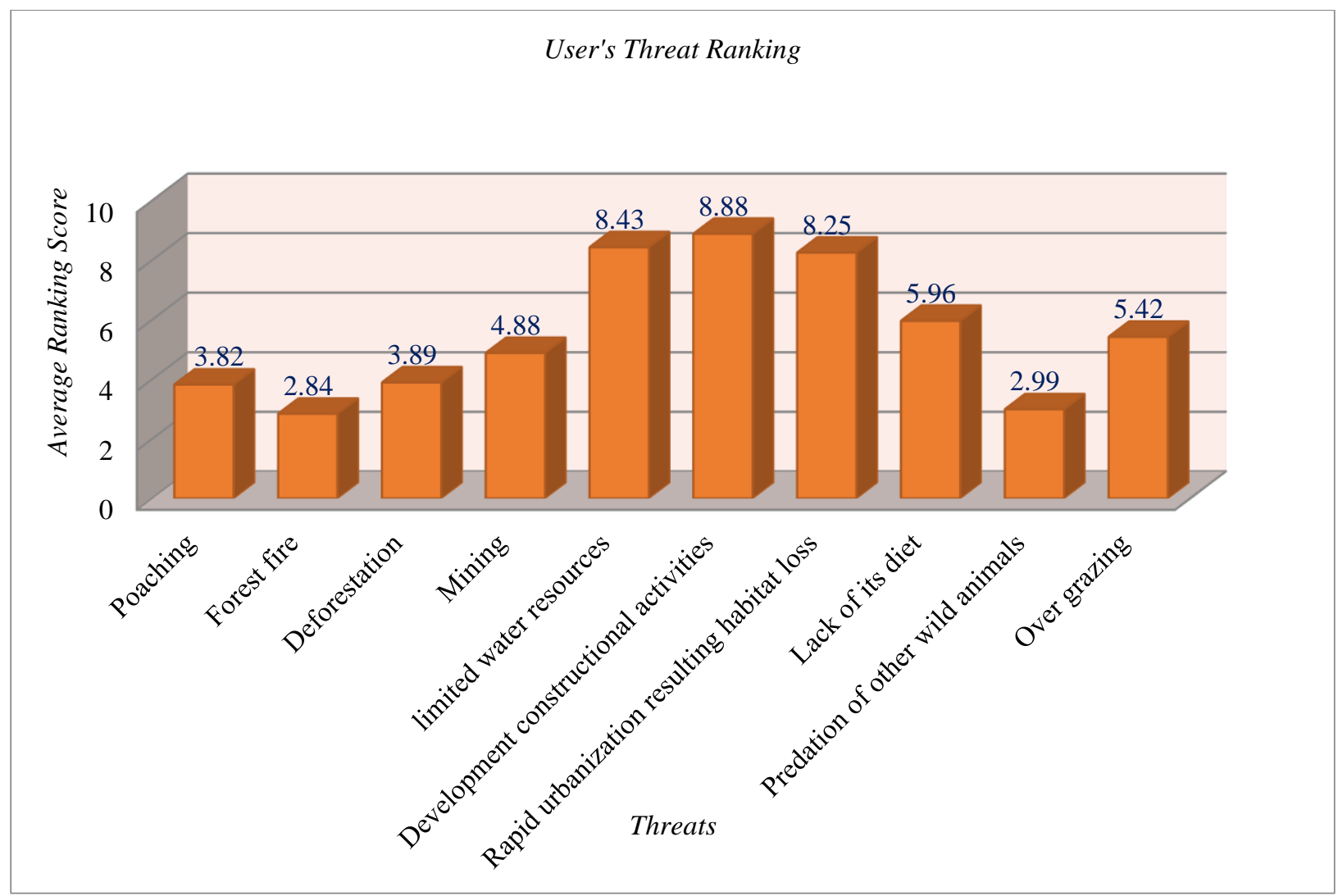

Figure3: Showing ranking score and ranking position of threats

As shown in Figure 3, among the major key threats, development construction activities had highest ranking score of 8.88. So, this threat could be considered as biggest threat to pangolin. According to Suwal (2011), forest fire, forest encroachment, poaching, and lack of public awareness were some of the risks that pangolin face today. Additionally, this research explored additional threats to the pangolin such as development construction activities, scarcity of water resources, lack of food, and so on.

\section{Community Based Conservation}

The Rani Community Forest had initiated different activities for the conservation and management of pangolin and its habitat. Some of the awareness programmes were observed under this study and are shown in table 4.

District level pangolin conservation interaction program was conducted 2 times in year 2015 and 2017. Similarly, school level awareness programs were conducted in year 2015, 2016 and 2017. 2000 brochures were published in year 2015, 2016 and 2017, whereas in 4 places hoarding boards were placed in year 2015. Under this program, various activities were initiated that had helped to protect the habitat of pangolin as well as other wild animals. Some of the important activities were:

- Patrolling and surveying of the forest from time to time.

- Control of forest fire by constructing fire line inside forest.

- Control of grazing by implementing system of block wise rotational grazing.

- Restriction on entering inside block " 2 " and " 3 " of this CF. 
Doi: https://doi.org/10.33002/nr2581.6853.02124

- Networking and coordinating with neighboring CF by conducting local as well as district level protection networking group.

- System of reward to the conservation of pangolin.

Table 4: Different awareness programs conducted by Rani Community Forest

\begin{tabular}{|c|c|c|c|c|c|}
\hline \multirow[t]{2}{*}{ Program } & \multirow[t]{2}{*}{ Conducted } & \multirow{2}{*}{$\begin{array}{l}\text { Financial } \\
\text { Contribution }\end{array}$} & \multicolumn{3}{|l|}{ Year } \\
\hline & & & 2015 & 2016 & 2017 \\
\hline $\begin{array}{l}\text { District level pangolin conservation } \\
\text { interaction program }\end{array}$ & 2 times & Rs.30,950 & & & \\
\hline School level awareness & 5 times & Rs. 20,750 & & & \\
\hline Publication of brochures & 2000 publications & Rs. 25,500 & & & \\
\hline Placement of hoarding board & 4 places & Rs. 20,000 & & & \\
\hline
\end{tabular}

Source: Division Forest Office, Makwanpur

Regarding effectiveness of such program, out of 79 respondents, 38 respondents $(48 \%)$ said that various community-based conservation activities were effective for the conservation and protection of pangolin. 25 respondents (32\%) claimed that various conservation programs conducted were not effective whereas 16 respondents $(20 \%)$ said that they were unaware about the conservation program conducted by this $\mathrm{CF}$.

\section{Conclusion}

It can be concluded that there was occurrence of pangolin, which 'clumped' through the indirect sign (burrow) in Rani Community Forest. Key threats identified were poaching, mining, deforestation, scarcity of water resources, development construction activities, rapid urbanization resulting into habitat loss, lack of food, predation of other wild animals and overgrazing. Among them development construction activities were ranked as biggest threat and forest fire as a least threat to pangolin. Recently, a road construction was inside this community forest, which could be the reason that construction activities were ranked as severe threat. Various awareness programmes were conducted at school as well as community level that had helped to protect the habitat of pangolin, but these programmes were still not found to be effective for the conservation of pangolin.

\section{Acknowledgement}

The authors gratefully acknowledge the Faculty of Forestry, Agriculture and Forestry University, Nepal for providing fund for this research work. We would like to express our deepest gratitude to those genuine personalities that either directly or indirectly supported to conduct this project successfully.

\section{References}

Baral, H.S. and Shah, K.B. (2008). Wild Mammals of Nepal (1 ${ }^{\text {st }}$ edition). Kathmandu: Himalayan Nature.

Chakraborty, S., Ramakrishna, S. and Chakraborty, R. (2002). Pangolins (Mammlia: Pholiodota) of India. Zoological Society of India. ENVIS Newsletter, 9:5-9. 
Chalise, M.K. (2008). Nepalka Samrakshit Banyajantu (Nepal's Protected Wildlife in Nepali). Kathmandu, Nepal: Sajha Prakashan, pp.89-91.

Challender, D. (2009). Asian pangolins: How behavioural research can contribute to their conservation. In Workshop on trade and conservation of pangolins native to South and Southeast Asia, p.95.

Chao, J.T. (2001). General Status of Formosan Pangolin Manis pentadactyla. Pentadactyla. Workshop on Asian Pangolin, Taiwan, December (2001).

Dickman, C.R. and Richer, R.A. (2001). Pangolins. Pp.800-801. In D.W. Macdonald (ed.), The Encyclopedia of Mammals. New York: Facts on File.

Heath, M. (1992). Manis pentadactyla, Mammalian. Species, 414:1-6.

IUCN (2017). About the IUCN Red List. Gland, Switzerland: IUCN. Available online at: http://www.iucn.org/about/work/programmes/species/red_list/about the_red_list/index.cfm

Jnawali, S.R., Baral, H.S. Lee, S., Subedi, N., Acharya, K.P., Upadhyay, G.P., Pandey, M., Shrestha, R., Joshi, D., Lamichhane, B.R., Griffiths, J., Khatiwada, A. and Amin, R. (2011). The Status of Nepal's Mammals: The National Red List Series. Department of National Parks and Wildlife Conservation, Kathmandu, Nepal.

Raut, N. (2015). Pangolin conservation education kit submitted to The Rufford Foundation, p.29.

RSS (Rastriya Samachar Samiti) (2016). Nepal's 43 districts home to pangolin. Kathmandu Post. December 11, 2016. Online: https://kathmandupost.ekantipur.com/news/2016-12-11/nepals43-districts-home-to-pangolins.html

Shrestha, T.K. (2003). Wildlife of Nepal (Second Edition). Kathmandu, Nepal: Bimala Shrestha.

Suwal, T.L. (2011). Status, Distribution, Behaviour and Conservation of Pangolins in Private and Community Forest of Balthali in Kavre, Nepal. M.Sc. dissertation submitted to Central Department of Zoology, Tribhuvan University of Nepal.

The Himalayan Times (2018). Two Chinese held with $162 \mathrm{~kg}$ pangolin scales. The Himalayan Times, March 31, 2018.

Wu, S.B., Liu, N.F., Zhang, Y.M. and Ma, G.Z. (2004). Assessment of Threatened Status of Chinese Pangolin (Manis pentadactyla). Chinese Journal of Applied Environmental Biology, 10 (4): 456-461. 